\title{
Serbian adaptation of the Perceived Vulnerability to Disease (PVD) scale
}

\author{
Nikola Rokvić1, Vedrana Karan ${ }^{2}$ \\ ${ }^{1}$ Faculty of Legal and Business affairs “Dr Lazar Vrkatić”, Union University, Serbia \\ ${ }^{2}$ Department of Physiology, Faculty of Medicine, University of Novi Sad, Serbia
}

ABSTRACT

The year 2020 has shown the renewed importance of combating infectious diseases. Apart from the psychological immune system an individual possesses a behavioural immune system. Key components of this system are digest proneness, perceived vulnerability to disease, health anxiety and others. There is no instrument to measure perceived vulnerability to disease in the Serbian language so we undertook this research to provide the scientific community with a viable tool for researching this relevant topic, the Perceived Vulnerability from Disease scale (PVD). On a sample of 500 participants, out of the $82.6 \%$ identified as female, and the average age of 20.53 ( $\mathrm{SD}=1.27 ; \min =19 ; \max =26)$, we performed confirmatory factor analysis. Two existing models for the scales structure have not shown adequate model fit. Therefore, we have created a model that preserves the two-factor structure, the Perceived Infectability (PI) and the Germ Aversion (GA) subscales, but we had to lose two items to do so. We have tested the scale alongside other relevant constructs to determine its divergent validity and have found satisfactory results. In conclusion, the Serbian translation of the PVD is a valid instrument and can be used for further research.

Key words: PVD, disgust, validation

Primljeno- 27.februara 2021.; prihvaćeno- 26.januar 2022. ; objavljeno na internetu- 27. januara 2022.

DOI: $10.5937 /$ engrami43-31095 


\section{Introduction}

Given the events of 2020, and since it seems they will continue to affect 2021, we can see that infectious diseases are a major threat, not only to the lives of individuals, but to their quality of life in every respect - be it social, economic, health relates and other. Infectious disease is followed by a physiological immune reaction that has its drawbacks, such as temporarily impairing you to solve other adaptive problems, like attracting a mate or caring for offspring. Another set of defences has been erected to prevent the development of a disease, and this is the behavioural immune system [1].

Individuals that perceive themselves to be more vulnerable to disease tend to react to pathogen cues with ethnocentrism and decreased sociability [2]. The behavioural immune system tends to overgeneralize because infectious diseases have a large number of manifestations. Evolutionary, it is not possible to detect each one of them specifically. This is why disgust reaction can be triggered by the presence of phenomena other than pathogens such as disfigurements, disabilities, obesity, and elderly appearance [3]. The behavioural immune system can generally act in two ways:

reactively - a response to immediate cues such as smell or seeing someone with open sores, thus triggering prophylactic behaviour, and withdrawal,

proactively - aimed at managing long term threat to illness such as hygiene habits.

As we have said that one of the reactions of the behavioural immune system can be ethnocentrism, this can be projected down to social groups and all non-members can be perceived as individuals with a high risk of infection. It leads to the specific perception of these individuals - with disgust, negative attitudes. As a result, they are being avoided [4]. Individuals with an elevated feel of vulnerability to infectious diseases will greatly exaggerate their response in the form disgust, negative attitudes, and social recoil against those they perceive as a treat. The exact etiology of this behaviour is still a matter of debate. There are twin studies that indicate $40 \%$ of contamination sensitivity variance is explained genetically [5]. This suggests that parental modelling is the prevailing factor in traits clustered around disgust and disease avoidance.

Disease avoidance manifests itself in many different ways. This can be on the level of individual differences, but also influenced by environmental factors such as where, in a 
geographical sense, and when, in a seasonal sense [6]. With this in mind, cultures have developed specific types of behaviour regarding, for instance, food preparation, parenting, and marriage practices that reflect a more conservative attitude. For example, in European cultures, this means that individuals who score higher on disease avoiding behaviour have fewer pets than those that do not [7].

These behavioural pattern results came to a test with the COVID19 pandemic. It has been found that the elderly, females in particular, those with greater education, and those with no ability to work remotely, perceived higher vulnerability to disease [8]. The perceived vulnerability was also connected to a greater belief in government measures but also criticism of the government. Pre pandemic disgust proneness has been seen as a factor influencing pandemic anxiety and a possible predilection for developing anxiety disorders during the pandemic [9].

There are three forms of instruments used to measure perceived vulnerability to disease. First of all, there are the disgust scales that ascertain the level of disgust felt by an individual. They can be classified as those measuring disgust sensitivity by using items containing disgust elicitors, or those that measure general trait disgust [10]. The second is the scales measuring hypochondria and health-related anxiety. These instruments suffer from a lack of focus on infectious diseases that also encompass cancer, cardiovascular disorders, and similar prevailing non-infectious illnesses.

To correct this, the Perceived Vulnerability to Disease scale (PVD) was created [11]. This first instrument has undergone a lot of changes over time. This includes adding and subtracting items, as well as changing the way responses are scored on the seven-point Likers scale of dichotomic yes/no answers. But one thing remained constant during this remodelling of the original instrument: there always remained the two initial subscales, Perceived Infectability (PI) and Germ Aversion (GA) [4].

Perceived Infectability can be considered as a subjective assessment of disease susceptibility, while Germ Aversion is considered discomfort within an environment where there is an increased possibility of getting in contact with disease-causing germs.

In general, female examinees have scored higher on both scales. The proposed explanation for this finding is that female participants generally score higher on pathogen disgust sensitivity scales [12]. There are differences in how much of trait disgust proneness is 
explained by genetic factors in males and females, and it comes out as more pronounced with females [13].

The use of PVD in literature has been inconsistent. There are three ways it has been used, with two subscales Perceived Infectability and Germ Aversion, Perceived Infectability only, and as a cumulative score. Low internal consistency of the Germ Aversion scale ranging from .55 to 61 Crombach's alpha values in some studies has led some researchers to abandon it [4]. In our research we have decided to try and test a bifactorial model proposed by Duncan et al [14], a reduced bifactorial model proposed by Diaz et al [4], and if necessary, create a model that will fit our own data because of the potential influences of cultural differences.

\section{Aim}

The aim of this study is to translate the PVD scale to the Serbian language and determine if it can be used in further research pending it maintains it structure.

\section{Method}

The sample consisted of students that voluntarily filled out a paper and pencil questionnaire. The questionnaire itself contained information about how the data will be used and filling the questionnaire represented informs consent to participate in the study. The survey was performed over a period of a month on lectures by attending students. The sample numbered 500 participants, out of the $82.6 \%$ identified as female, and the average age of $20.53(\mathrm{SD}=1.27 ; \min =19 ; \max =26)$. Except for this no other demographic variables were taken. We used descriptive statistics methods, bivariate correlation, t-test, linear regression and confirmatory factor analysis. Descriptive statistics were used to describe the sample used in our study, further we used t-test in order to determine gender differences in measured constructs, correlation was used to determine the relationship between measured constructs, we used regression analysis in order to determine if our chosen models determined the variance of the PVD scale, and in what way. Further we used confirmatory factor analysis as the most complex procedure to determine the model fit of the scale in our sample. This sample was collected before the COVID19 pandemic. Two separate translators adapted the text of the scale to the Serbian language, then the two translations were fused into one by a Serbian language expert, under the supervision of a psychologist. The scale was not backtranslated and sent to original authors for supervision. WE used some of the instruments used 
in Duncan et al (2009) original work so that we can further prove the validity of our translation by referring to this seminal study.

Considering indicators of the good model fit we used is Root Mean Square Error of Approximation (RMSEA). We placed the maximum acceptable value at .08, while we took $<0.05$ to reflect a good model fit [15]. Furthermore, we used the Comparative Fit Index (CFI) and the Tucker-Lewis Index (TLI) to determine the goodness of fit. For both indexes we considered values of at least 0.90 to indicate an acceptable model fit, while values of 0.95 and above represent a good solution [16,17]. The last two parameters we used were the Akaike's Information Criteria (AIC) and the Baysian Information Criterion (BIC), where models with lower AIC and BIC are considered to be indicators of better model fit $[18,19]$.

\section{Instruments}

Perceived Vulnerability to Disease Scale - (PVD) [14] is a 15-item scale consisting out of two subscales, Perceived infectability (PI) consisting out of seven items ("In general, I am very susceptible to colds, flu and other infectious diseases."), and Germ aversion (GA) consisting out of eight items ("I do not like to write with a pencil someone else has obviously chewed on."). The answers are registered on a 7-point Likert scale. The scale was translated into Serbian by a professional translator and edited by two bilingual psychologists. Items contained in the PI subscale are $8,12 \mathrm{R}, 2,14 \mathrm{R}, 10,5 \mathrm{R}, 6$ and in the GA subscale $7,15,4,9,3 \mathrm{R}, 1,13 \mathrm{R}, 11 \mathrm{R}$. Items denoted with $\mathrm{R}$ are reverse coded.

Satisfaction with life scale - (SWLS) [20] is a five-item scale measuring the cognitive aspect of life satisfaction. Answers are recorded on a five-point Likert scale. The scale has been successfully translated and validated to the Serbian language [21]. Internal consistency is within tolerable range with an alpha value of 0.77 .

International Personality Item Pool - (IPIP-6) [22] is a 24-item personality inventory based on the six-factor HEXACO model. It measures the original Big Five plus the honestyhumility scale that we have omitted. Answers are registered on a seven-point scale. The scale was translated and validated in the Serbian language [23]. Internal consistency of the fouritem subscales varied from 0.64 to 0.75 .

Disgust propensity and sensitivity scale - (DPSS) [24] is a twelve-item scale consisting out of two six-item subscales named disgust propensity (DP) and disgust sensitivity (DS). 
Answers are registered on a five-point Likert scale. The scale was successfully translated and validated in the Serbian language [10]. Internal consistency of the subscales is good with alpha values of 0.74 for DP and 0.78 for DS.

Depression, Stress and Anxiety Scale 21 - (DASS21) [25] is a 21-item scale measuring depression, anxiety, and stress, factors of psychological distress. Each subscale consists out of seven items and the answers are registered on a 4-point Likert scale. The scale was successfully translated and validated in the Serbian language [26]. In our research, we have only used the anxiety subscale, and its internal consistency was acceptable within alpha value of 0.76 .

\section{Results}

We have conducted a confirmatory factor analysis on our sample in order to determine the validity of the factor structure of the Perceived vulnerability to disease scale. We have tested several models. Model 1 is the original model used by the creators of the scale, it consists of two subscales [14], Perceived vulnerability (PV) and Germ aversion (GA). The scales consist out of seven and eight items respectively. The second model we tested was one proposed later in a revision of the scale [4], with items 13 and 11 removed from the Germ aversion subscale. The third model we came up with by analyzing results and it has items 14 and 13 removed, one from each subscale. The results of the confirmatory factor analysis can be found in table 1 . Since the third model proved to be a superior fit, we have used it in further analysis. The representation of respective item weights can be seen in graph 1.

Table 1.

Result of a confirmatory factor analysis for the three proposed models.

\begin{tabular}{lllllll}
\hline & CFI & TLI & RMSEA & AIC & BIC & $\chi^{2}(\mathrm{df})$ \\
\hline Model 1 & 0.823 & 0.791 & 0.09 & 506.868 & 637.521 & $444.959(89)$ \\
Model 2 & 0.860 & 0.829 & 0.091 & 383.135 & 496.929 & $329.135(64)$ \\
Model 3 & 0.921 & 0.91 & 0.067 & 257.395 & 379.618 & $199.395(62)$ \\
\hline
\end{tabular}




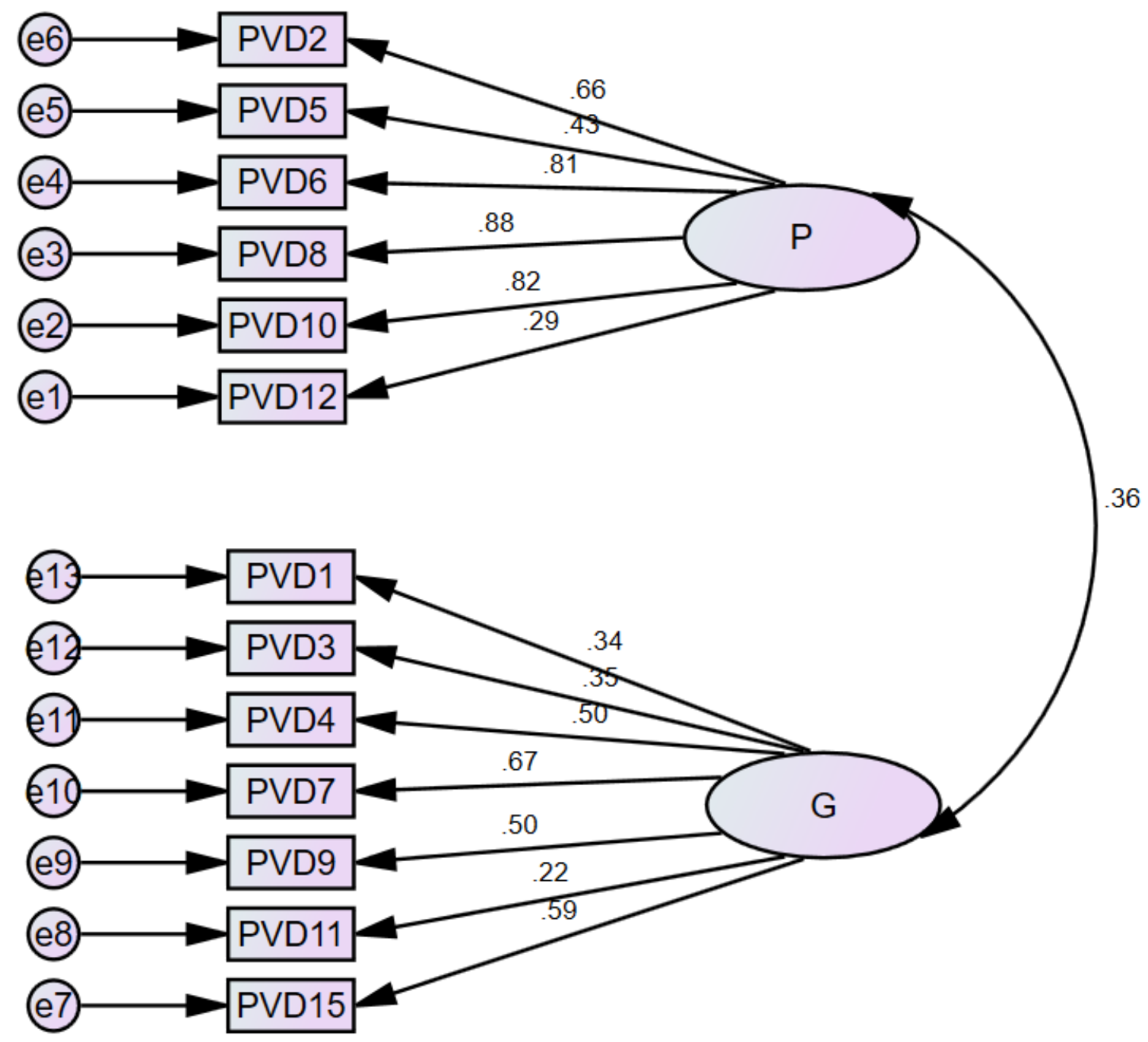

\section{Graph 1.}

The value of the PI subscale for our sample is 3.08 ( $\min =1 ; \max =7 ; \mathrm{SD}=1.11$ ) and for the GA subscale is 3.92 ( $\min =1 ; \max =7 ; \mathrm{SD}=1.04)$. We have correlated the measured constructs and the results can be found in table 2. There are no gender differences on the PI scale (3.06; $\mathrm{SD}=1.11$ for female participants and 3.17; $\mathrm{SD}=1.16$ for male participants), but female participants score (3.96; $\mathrm{SD}=1.03$ ) significantly higher than the male score $(3.7, \mathrm{SD}=1.08)$ on the GA scale $(\mathrm{p}=0.032)$. This result was achieved by using the $t$-test. We have conducted a regression analysis with PI and GA as dependant variables and the Big Five and disgust proneness, as stable personality traits, as independent variables. For PI the results of the regression model were significant $(\mathrm{F}(\mathrm{df})=10.297(492) ; \mathrm{p}<0.001)$ and it explained $12.8 \%$ of the PI variance. When GA is concerned the regression model is also valid $(\mathrm{F}(\mathrm{df})=13.115(492)$; 
$\mathrm{p}<0.001)$ with the model explaining $15.7 \%$ of the variance. The in depth results of the regression analysis can be found in table 3 .

Table 2.

Correlations between measured constructs and PVD subscales.

\begin{tabular}{|c|c|c|}
\hline & Perceived invulnerability & Germ aversion \\
\hline Perceived invulnerability & - & \\
\hline Germ aversion & $0.21 * *$ & - \\
\hline Satisfaction with life & - & \\
\hline Anxiety & $0.21 * *$ & $0.17 * *$ \\
\hline Disgust propensity & $0.18 * *$ & $0.31 * *$ \\
\hline Disgust sensitivity & $0.27 * *$ & $0.2 * *$ \\
\hline Neuroticism & $0.24 * *$ & $0.15 * *$ \\
\hline Extraversion & & - \\
\hline Agreeableness & & - \\
\hline Conscientiousness & $-0.10 *$ & $0.19 * *$ \\
\hline Openness & $-0.12 * *$ & - \\
\hline
\end{tabular}

$* \mathrm{p}<0.05 ; * * \mathrm{p}<0.001$

Table 3.

Regression analysis results.

\begin{tabular}{lcccccc}
\hline & \multicolumn{3}{c}{ Perceived Vulnerability } & \multicolumn{3}{c}{ Germ Aversion } \\
\cline { 2 - 7 } & $\beta$ & $\mathrm{t}$ & sig. & $\beta$ & $\mathrm{t}$ & sig. \\
\hline Neuroticism & 0.193 & 4.349 & $<0.001$ & 0.136 & 3.108 & 0.002 \\
Extroversion & 0.037 & 0.819 & 0.413 & 0.017 & 0.397 & 0.692 \\
Agreeableness & 0.028 & 0.602 & 0.547 & -0.120 & -2.611 & 0.009 \\
Conscientiousness & -0.077 & -1.781 & 0.075 & 0.221 & 5.175 & 0.000 \\
Openness & -0.123 & -2.693 & 0.007 & 0.023 & 0.509 & 0.611 \\
\hline
\end{tabular}




\begin{tabular}{lcccccc}
\hline Disgust propensity & 0.054 & 1.052 & 0.293 & 0.242 & 4.771 & 0.000 \\
Disgust sensitivity & 0.193 & 3.742 & $<0.001$ & 0.057 & 1.129 & 0.259 \\
\hline
\end{tabular}

$\beta$-beta value; t- $t$-test value; sig.-significance

\section{DISCUSSION}

We have performed a confirmatory factor analysis to determine the structure of the Serbian translation of the Perceived Vulnerability to Disease Questionnaire. To do so, we have chosen several models to test. First, we have tested the model proposed by Duncan et al [14] a 15-item model with two subscales, Perceived Infectability and Germ Aversion. This however has not proven to be satisfactory. Across all observed parameters of the goodness of fit, we have found suboptimal values. Next, we have tried the model proposed by Diaz et al [4] that removed two items from the Germ aversion scale. This model scored better than the first one but still fell well short of the desired model fit values.

Next, we examined our data, eliminated items 13 and 14 because of low factor loading and covaried the standard errors between items 10 and 2 and 5 and 12. This has proven to be the correct intervention in our sample. We have achieved acceptable values on all observed, model-fit parameters. Still, one thing remains, and that is the low Crombach's alpha value on the Germ Aversion scale. This is proving to be a systemic problem with this scale, and we have not been able to fix it in our model. Although we can contribute the differences in the model to, in some way, cultural differences, the lack of GA's internal stability is a systemic problem. We can recommend the usage of the PI subscale with a great degree of certainty on the other hand we must suggest caution when GA usage is concerned.

The next test of validity is gender differences in mean scores. Here we encountered small difficulties, although higher values in females were expected [14]. Indeed this is not the first time this had happened. Diaz et al [4] have found that there are no significant gender differences in Perceived Infectability, and none in Germ Aversion scores. Our study shows the opposite. There are no differences in Perceived Infectability but there are significant differences in the Germ Aversion score. Though we have shown that there are gender differences, their specificity is certainly affected by the type of model used in other studies, and by cultural differences of the sample population. Since we have not found instances of PVD use and translation to Slavic and Eastern European populations, we cannot compare our results to other existing studies. 
With regards to the relationship between personality traits and perceived vulnerability to disease, results in studies differ. Diaz et al [4] find no relationship between neuroticism, extroversion, and psychoticism with PVD subscales. However, they have used the EPQ questioner and model in their study, so this can account for the discrepancy. In our study, we have found a moderate correlation between perceived infectability and neuroticism, as well as a low correlation between Germ Aversion and neuroticism. On the other hand, we have also found no correlation between extraversion and both PVD subscales partially replicating the results of their study.

We have used the Big Five personality traits paradigm, just like Duncan et al [14], which makes the results more compatible and easier for interpretation. Duncan et al [14] found a low negative correlation between Pi and GA and agreeableness that is absent from our study. When extroversion is concerned we have replicated the result that there is no significant relationship between this construct and PI, but they have found a low negative correlation between it and GA, a result that we did not replicate. Therefore, we have only partially corroborated their results in terms of the relationship between extraversion and PVD subscales.

Next, we turn to conscientiousness where both studies register a negative correlation between $\mathrm{Pi}$ and this construct. The difference is in the relationship with GA, where the previous study does not register any significant correlations, but we find a low positive correlation. It seems that in our sample there is a small perceived overlap between germ aversion and conscientious behavior, but the correlations are small and this requires further research. When neuroticism is concerned, both studies show the same results, a low positive correlation, only that in our study there is a stronger connection between neuroticism and PI. An interesting inversion has been registered when considering openness to experience. While Duncan et al [14] report that there is a week negative correlation between openness and GA, we did not find this. On the other hand, in our ample, we detect a week negative correlation between openness and PI that the aforementioned study did not report. On the whole, we believe that the relationship between our translation of PVD and personality traits is within expectations and that it corroborates to an extent the Serbian version's divergent validity.

These week or non-existent correlations reflected themselves in the regression models we have created. We used $\mathrm{Pi}$ and $\mathrm{Ga}$ as dependant variables and personality traits as independent variables in creating our models. All in all, the models explained very little of 
the PVD subscale variance, with adjusted R2 values of .068 and .072 respectively. This leads us to believe that factors other than personality determine the majority of the variance regarding the disease vulnerability and, by extension, the behavioural immune system.

Any talk of divergent validity would be incomplete without testing the PVD scale alongside a scale measuring disgust. At the time, the only available working scale was the Disgust Sensitivity and Propensity scale. On the one hand, it measures disgust proneness as a personality trait, it does not measure specifically pathogen disgust, but more an individual's disposition. This must be taken into account when interpreting the strength of the correlations registered in our research.

Elicitor based scales measuring pathogen disgust, such as the Digest Sensitivity scale and the Three Domains of Disgust scales, have been used in several studies [14, 4, 27], and they have found high correlations between Germ Aversion and all variations of pathogen disgust. The same is not true for Perceived Infectability that, while it correlates positively with these constructs, the strength of this correlation can be twice as weak in some cases. This is not the case with disgust proneness. Perceived Infectability and Germ aversion correlate positively with Disgust Propensity and Disgust Sensitivity, but this correlation is relatively weak. In fact, it is more pronounced in PI than in GA, raising interesting questions about the exact mechanisms behind these constructs.

We have not found any instance in the literature about the relationship between life satisfaction and perceived vulnerability to disease. We postulated that increased levels on PVD scales would be some kind of impairment on daily activities and reduce the quality of life in some manner. As it happens, this hypothesis has not proven to be correct. This might be the case because of the choice of the instrument.

The Satisfaction with Life Scale is a self-report measure of the cognitive aspect of wellbeing. It is perhaps because of this cognitive approach that we find no impact on life satisfaction, since people with an increased feeling of disease vulnerability believe themselves to be correct in their assertions. Perhaps precise testing of other quality of life aspects would yield different results, but as it stands, we cannot make any meaningful connection between life satisfaction and perceived vulnerability to disease in a non-pandemic setting.

We have also measured general anxiety in our study. There have been examples of a strong correlation between health-related anxiety and Perceived Infectability (Duncan, 
Schaller, \& Park, 2009). We believed that similar but weaker results, since the instrument is more general in nature, will be found in our study, and it was so. Anxiety correlates weakly positively with PI and GA. This furthers our claim for the validity of the scale's translation, and our model of its factor structure.

\section{Conclusion}

After testing the available structure models, we have found that the one we created based on our results is best for use in the Serbian translation of the PVD, showing a good model fit. Its relationship with other instruments used in the battery of tests shown is as expected and furthers our claim to the translation's validity. Even with this, we must caution future researchers in the use of the Germs Aversion subscale because of its low internal consistency that has been reported throughout literature and confirmed in our study.

\section{Limitations}

One of the limitations of this study is that only a sample of medical students was used, not a broader sample of students from different faculties. We did not use the back translation procedure in this study. 


\title{
Srpska adaptacija Skale ranjivosti prema zaraznim bolestima (PVD)
}

\author{
Nikola Rokvić1, Vedrana Karan² \\ ${ }^{1}$ Fakultet za pravne i poslovne studije „Dr Lazar Vrkatić“, Univerzitet Union, Srbija \\ ${ }^{2}$ Katedra za fiziologiju, Medicinski fakultet, Univerzitet u Novom Sadu, Srbija
}

\section{Sažetak}

Godina 2020 je pokazala u novom svetlu značaj borbe protiv infektivnih bolesti. Pored fiziološkog imunog sistema individua poseduje i bihevioralni imuni sistem. Ključne komponente ovog sistema su sklonost ka gađenju, percipirana ranjivost u odnosu na bolesti, zdravstvena anksioznost $\mathrm{i}$ druge. Trenutno ne postoji ni jedan instrument koji meri percipiranu ranjivost prema bolesti na srpskom jeziku. Iz tog razloga sproveli smo istraživanje kako bismo stručnoj javnosti obezbedili instrument koji bi omogućio istraživanja ove vrlo aktuelne i relevantne teme, Skale ranjivosti prema zaraznim bolestima (Perceived Vulnerability to Disease Scale; PVD). Na uzorku od 500 ispitanika, od kojih se $82.6 \%$ izjasnilo da su ženskog pola, sa srednjom vrednosti starosti od 20.53 godine $(\mathrm{SD}=1.27$ $\min =19$; $\max =26$ ), izvršili smo konfirmatornu faktorsku analizu. Postojeća dva modela strukture skale nisu pokazali zadovoljavajuću podudarnost. Zbog toga smo primenili dvofaktorsko rešenje koje odgovara našim nalazima. Dve subskale su Percepcija opasnosti od zaraze (PI) i Averzija prema mikrobima (GA) ali morali smo da izbacimo dve stavke kako bismo dobili ovo rešenje. Testirali smo ovu skalu sa drugim konstruktima kako bismo utvrdili divergentnu validnost i dobili smo zadovoljavajuće rezultate. Zaključujemo da je srpski prevod PVD skale validan instrument koji se može koristiti u daljim istraživanjima.

Ključne reči: PVD, gađenje, validacija. 


\section{LITERATURE}

1. Murray D, \& Schaller M. The behavioral immune system: Implications for social cognition, social interaction, and social influence. Adv Exp Soc Psychol 2016; 53: 75129.

2. Mortenson C, Becker D, Ackerman J, Neuberg S, \& Kenrick D. Infection breeds reticence the effects of disease salience on self-perceptions of personality and behavioral avoidance tendencies. Psychol Sci 2010; 21(3): 440-477.

3. Ackerman J, Hill S, \& Murray D. The behavioral immune system: Current concerns and future directions. Soc Personal Psychol Compass 2018; 12(2).

4. Diaz A, Soriano J, \& Belena A. Perceived Vulnerability to Disease Questionnaire: Factor structure,psychometric properties and gender differences. Pers Individ Dif 2016; 101: 42-49.

5. Tybur J, Wessekdijk L, \& Jern P. Genetic and Environmental Influences on Disgust Proneness, Contamination Sensitivity, and Their Covariance. Clin Psychol Sci 2020; 8(6): 1054-1061.

6. Schaller M, \& Murray D. Pathogens, personality and culture: Disease prevalence predictors worldwide variability in sociosexuality, extraversion, and openness to experience. J Pers Soc Psychol 2008; 95(1): 212-221.

7. Prokop P, Usak M, \& Fancovicova J. Risk of parasite transmission influences perceived vulnerability to disease and perceived danger of disease-relevant animals. Behav Processes 2010; 85(1): 52-57.

8. De Coninck D, d'Haenens L, \& Matthijs K. Perceived vulnerability to disease and attitudes towards public health measures: COVID-19 in Flanders, Belgium. Pers Individ Dif 2020. 166. 
9. Cox R, Jessup S, Lueber M, \& Olatunji B. Pre-pandemic disgust proneness predicts increased coronavirus anxiety and safety behaviors: Evidence for a diathesis-stress model. J Anxiety Disord 2020; 76.

10. Rokvic N. Validation of the Serbian Translation of the Disgust Propensity and Sensitivity Scale (DPSS). Psihologijske teme 2020; 29(3): 631-648.

11. Park J, Faulkner J, \& Schaller M. Evolved disease-avoidance processes and contemporary anti-social behavior: Prejudicial attitudes and avoidance of people with physical disabilities. Journal of Nonviolent Behavior 2003; 27: 65-87.

12. Olatunji B, Adams T, Ciesielski B, David B, Sarawagi S, \& Broman-Fulks J. The three domains of disgust scale: Factor structure, psychometric properties, and conceptu al limitations. Assessment 2012; 19(2): 205-225.

13. Olatunji B, Taylor S, \& Zald D. Sex differences in the etiology of disgust sensitivity: A preliminary behavioral genetic analysis. J Anxiety Disord 2019; 65: 41-46.

14. Duncan L, Schaller M, \& Park J. Perceived vulnerability to disease: Development and validation of a 15-item self-report instrument. Pers Individ Dif 2009; 47(6): 541546.

15. Browne MW, \& Chudeck R. Alternative ways of assessing model fit. In KA Bollen, \& JS Long, Testing structural equation models (pp. 136-162). Newbury Park CA: Sage; 1999.

16. Bentler PM. Comparative fit indexes in structural models. Psychol Bull 1990; 107(2): 238-246.

17. Tucker L, \& Lewis C. A reliability coefficient for maximum likelihood factor analysis. Psychometrika 1973, 38, 1-10.

18. Akaike H. Factor Analysis and AIC. In E Parzen, K Tanabe, \& G Kitagawa, Selected Papers of Hirotugu Akaike. Springer Series in Statistics (Perspectives in Statistics) (pp. 371-386). New York: Springer; 1987.

19. Schwarz G. Estimating the dimension of a model. Ann Stat 1978; 6(2): 461-464.

20. Diener E, Emmons R, Larson R, \& Griffin S. The Satisfaction With Life Scale. J Pers Assess 1985; 49(1): 71-75. 
21. Vasić A, Sarčević D, \& Trogrlić A. Zadovoljstvo zivotom u Srbiji [Life satisfaction in Serbia]. Primenjena psihologija 2011; 4(2): 151-177.

22. Ashton M, Lee K, \& Goldberg L. The IPIP-HEXACO scales: An alternative, publicdomain measure of the personality constructs in the HEXACO model. Pers Individ Dif 2007, 42(8), 1515-1526.

23. Medjedovic J, \& Bulut T. The mini IPIP-6: short, valid, and reliable measure of the six-factor personality structure. Primenjena psihologija 2017; 10(2): 185-202.

24. Cavanagh K, \& Davey G. The development of a measure of individual differences in disgust. British Psychology Society 2000. Winchester, UK.

25. Lovibond P, \& Lovibond S. The Structure of Negative Emotional States: Comparioson of the Depression, Anxiety, Stress Scales (DASS) with the Beck Depression and Anxiety Inventory. Behav Res Ther 1995; 33(3): 335-343.

26. Jovanovic V, Gavrilov-Jerkovic V, Zuljevic, D, \& Brdaric D. Psihometrijska evaluacija Skale depresivnosti, anksioznosti i stresa-21 (DASS-21) na uzorku studenata u Srbiji [Psychometric evaluation of the Depression Anxiety Stress Scales21 (DASS21) in a Serbian student sample]. Psihologija 2014; 47(1): 93-112.

27. Magallares A, Fuster-Ruiz De Apodaca M-J, \& Morales J-F. Psychometric properties and criterion validity of the Perceived Vulnerability to Disease Scale (PVD) in the Spanish population. Rev Psicol Soc 2017; 32(1): 164-195. 


\section{Supplement}

Molim Vas označite koliko se svaka od sledećih izjava odnosi na Vas. (PVDsr)

\begin{tabular}{|c|c|c|c|c|c|c|c|}
\hline & \multicolumn{2}{|c|}{$\begin{array}{l}\text { Uopšte } \\
\text { se ne } \\
\text { slažem }\end{array}$} & & & & \multicolumn{2}{|c|}{$\begin{array}{c}\text { Potpuno } \\
\text { se } \\
\text { slažem }\end{array}$} \\
\hline Smeta mi kada ljudi kijaju, a ne pokriju usta. & 1 & 2 & 3 & 4 & 5 & 6 & 7 \\
\hline Ukoliko „hara“ neka bolest, sigurno ću se zaraziti. & 1 & 2 & 3 & 4 & 5 & 6 & 7 \\
\hline $\begin{array}{l}\text { Nemam problem da pijem iz iste flaše kao moj } \\
\text { prijatelj. }\end{array}$ & 1 & 2 & 3 & 4 & 5 & 6 & 7 \\
\hline $\begin{array}{l}\text { Ne volim da pišem olovkom koju je neko pre toga } \\
\text { očigledno grickao. }\end{array}$ & 1 & 2 & 3 & 4 & 5 & 6 & 7 \\
\hline $\begin{array}{l}\mathrm{Na} \text { osnovu ranijih iskustava najverovatnije se neću } \\
\text { razboleti čak iako su mi prijatelji bolesni. }\end{array}$ & 1 & 2 & 3 & 4 & 5 & 6 & 7 \\
\hline Uvek sam bio/la podložan/la zaraznim bolestima. & 1 & 2 & 3 & 4 & 5 & 6 & 7 \\
\hline $\begin{array}{l}\text { Volim da operem ruke vrlo brzo nakon što se } \\
\text { rukujem sa nekim. }\end{array}$ & 1 & 2 & 3 & 4 & 5 & 6 & 7 \\
\hline $\begin{array}{l}\text { Opšte uzevši jako sam podložan prehladama, } \\
\text { gripama i drugim zaraznim bolestima. }\end{array}$ & 1 & 2 & 3 & 4 & 5 & 6 & 7 \\
\hline $\begin{array}{l}\text { Ne volim da nosim korišćenu odeću jer nikad ne znaš } \\
\text { kakva ju je osoba nosila pre tebe. }\end{array}$ & 1 & 2 & 3 & 4 & 5 & 6 & 7 \\
\hline $\begin{array}{l}\text { Od ljudi u mom okruženju ja ću se najverovatnije } \\
\text { pokupiti neku zarazu. }\end{array}$ & 1 & 2 & 3 & 4 & 5 & 6 & 7 \\
\hline $\begin{array}{l}\text { Ne osećam da su mi prljave ruke nakon što sam } \\
\text { dirao/la novac. }\end{array}$ & 1 & 2 & 3 & 4 & 5 & 6 & 7 \\
\hline $\begin{array}{l}\text { Malo je verovatno da ću se zaraziti od gripe, prehlade } \\
\text { ili nekog drugog virusa čak iako „hara okolo“. }\end{array}$ & 1 & 2 & 3 & 4 & 5 & 6 & 7 \\
\hline Nije mi neprijatno da budem oko bolesnih ljudi. & 1 & 2 & 3 & 4 & 5 & 6 & 7 \\
\hline $\begin{array}{l}\text { Moj imunitet me štiti od većine bolesti koje dobiju } \\
\text { drugi ljudi. }\end{array}$ & 1 & 2 & 3 & 4 & 5 & 6 & 7 \\
\hline $\begin{array}{l}\text { Izbegavam da koristim javne i tuđe telefone jer } \\
\text { mislim da postoji rizik da ću se zaraziti nečim od }\end{array}$ & 1 & 2 & 3 & 4 & 5 & 6 & 7 \\
\hline
\end{tabular}


osobe koja ga je prethodno koristila.

Perceived vulnerability to disease items $-8,12 \mathrm{R}, 2,14 \mathrm{R}, 10,5 \mathrm{R}, 6$

Germ aversion items - 7, 15, 4, 9, 3R, 1, 13R, 11R 